\title{
Becoming Teachers, Becoming Researchers: a Case Study
}

\author{
Charly Ryan* \\ Faculty of Education, Health and social care, University of Winchester, SO22 4NR, UK \\ *Corresponding author: charly.ryan@winchester.ac.uk
}

Received June 03, 2014; Revised July 15, 2014; Accepted July 24, 2014

\begin{abstract}
This paper presents a case study of a group in initial primary teacher education students becoming researchers of their peers' course experiences of school - university links. The connection between university teacher preparation programmes and work in school is a well-researched area with suggestions that there is a marked disconnect between the two. The project took an emergent approach to learning researching through carrying out a research project. Unlike many studies, both students and tutors were able to identify a range of links between their work in school and work in the university. Outcomes are presented for the becoming teachers as becoming researchers and as becoming teachers, as well as for the programme as a whole.
\end{abstract}

Keywords: student researcher, reflective practice, initial teacher education

Cite This Article: Charly Ryan, "Becoming Teachers, Becoming Researchers: a Case Study." American Journal of Educational Research, vol. 2, no. 8 (2014): 585-591. doi: 10.12691/education-2-8-4.

\section{Introduction}

There is a range of expectations for what might be the future demands on teachers in the twenty first century. The teachers who are currently leaving initial teacher education will probably be still working in 2060, or beyond as life expectations increase. In turn that means that if they are still teaching, their last students will be still working in the next century. The impacts of teacher education can be very long-term indeed and so we should be future focused. Of the range of possible issues that this paper will deal with are teachers as researchers, teachers as reflective practitioners, and their relationships with teaching and learning in initial teacher education. These issues are set in the context of a case study of developing teacher education students as researchers of their peers' experiences. The case develops in England where, as in many other countries, there is growing pressure for teachers to comply with an increasing number of norms, show how they demonstrate a wide range of competences to ensure that pupils meet centrally inspired requirements (Beauchamp, Clarke, Hulme, and Murray 2013).

\section{Thinking about Reflective Practice}

A quick search on the internet for reflective practice and teacher education returns over half a million hits, with more than 16000 since 2010. This wealth of papers generally argues that reflective practice is a 'good thing'. For some time there has been debate about the many and varied approaches to what we might mean by reflection and reflective practice. Zeichner (1994) writing twenty years ago claimed that the international spread of the move to include reflective practice in teacher education was an attempt to move away from the view of teacher as technician, applying the latest findings from educational research and curricula written by those remote from the classroom. However, while he argues that reflective practice along with action research or inquiry oriented teacher education might be little more than slogans, later work (Zeichner and Liu 2012) shows that some progress has been made. A range of factors impinge on what it means to reflect and how that reflection might develop practice.

The assumption in articles dealing with teacher reflection is that analysis of needs, problems, change processes, feelings of efficacy, beliefs are all factors that contribute to teacher professional development, be it through enhanced cognitions or new or improved practices (Avalos 2011, p18).

What is also becoming clearer is that reflection is easier to develop if it is taught (Samuels and Betts, 2007; MacLellan 2004). We also have to bear in mind that it reflection is not always a positive experience (Reynolds 2011). These points will be taken up in the section below on teaching and learning strategies.

\section{Students as Researchers}

There is now a realization that learning to teach and starting a professional career involves a complexity of factors and thinking (OECD 2004) rather than the simple application of evidence from research collected by others. There is growing evidence that changing teachers and changing practice is site-specific (Avalos 2011, Cordingley and Bell 2007). Implementing research 
outcomes involves changing teachers, changing curriculum and changing relationships and so becomes a research activity in itself (Cordingley and Bell 2007, Ryan 2012). The value of researching practice is shown by the increased gains in pupil attainment, behavior and attitudes (Cordingley 2011). However, the relationship between reflection and practice leaves much to be investigated. This case shows one possible way to meet this challenge for teacher education.

The sources for introducing students as researchers of their peers experiences comes from parallel work in school (Fielding 2007). What the work in school shows is that pupil researchers bring their particular viewpoint to the research and are able to make valuable contributions to research, to learning and teaching in schools, as well as learning a range of important processes. As in participatory work in general, students learn to become researchers, exercise their right to be heard and involved in what affects them, as well as developing collaboration and communication (Chambers 2002, Reason and Bradbury 2001, Tandoon 2008). Reason and Bradbury (2001, p1) provide a succinct summary of their rationale.

It seeks to bring together action and reflection, theory and practice, in participation with others, in the pursuit of practical solutions to issues of pressing concern to people, and more generally the flourishing of individual persons and their communities.

As well as these outcomes, there was an expectation that by researching peers experiences, participants would come to see the value of research, the value of collaboration and listening to the voices of other people involved. It was an attempt to move research from something that is known about to something lived, experienced and a way to see growth and change (Larrosa 2009). A second aspiration was that participants would see themselves as classroom researchers or teacher researchers and, importantly, the value of consulting and involving their pupils in their future practice. There is an expectation within their programme that they are becoming reflective practitioners. This means that they should be collecting evidence about what they plan and do and what their pupils learn as a consequence. They should at least be investigating their own practice as teachers when they are in school. An introduction to ways to investigate their own and their peers' experience should provide them with a good foundation to try similar approaches when they are working in school and so become more reflective in their professional practice.

\section{Pedagogy}

Three main aspects of pedagogy will be discussed in this section: staff-student relations and expectations; teaching research; teaching reflection. The illustrations in this section come from the first cohort; the second cohort followed a similar process thought the details matched their specific research project.

The bases for decisions about pedagogy are complex matching the complexity of classrooms, teaching and learning. The approach in this case was to draw on critical theory as a way to establish some ground rules. The first is that realization that a narrow focus on pre-specified outcomes is not necessarily in participants' best interests.
The view that "Good teachers get perfect ratings on teaching evaluations' can lead to teachers catering to the expressed needs of students, which, ultimately, can be damaging to students in the long term. The notion that 'There is a ready-made answer out there to the problem I'm experiencing' can also hurt students in the long run. The students' interests, I will argue in the next chapter, are not served by generic solutions but by practical wisdom exercised in particular situations. The latter implies listening to what and how students think and how they experience their learning, (Kreber 2013, p138).

Participants come to such experiences with many experiences of teaching and learning and implicit and explicit expectations of what will happen. As the expectation was that this module was to be based in participants' interests and needs rather than the tutor's, and to help develop independent thinking, the advice of the Ford Teaching Project (Elliott and Adelman, no date) was taken. To avoid students playing 'guess what is in teacher's head' (Korthagen, Loughran and Russell 2006) it was decided that the approach would be informal, unstructured and open ended. Participants would sit in a circle so that there was no privileging of a 'front', that the participants would identify what it was they wanted to investigate and the role of the tutor was to support them in that investigation. It is an emergent approach to learning about research through carrying out a project. The module, requiring 135 hours of participant study time, was one of a serious of options students could choose in the sixth semester of a four year programme of initial primary teacher education. The module assessment was to keep a reflective journal representing the developing thinking of the participant and then present an assignment showing how they had met the learning outcomes, shown below.

1. further develop critical understanding of approaches to teaching and learning

2. analyse and critically reflect upon 'critical incidents' in the context of the placement

3. evaluate and articulate progress against personal / professional targets

4. show an understanding of how their voluntary work contributes to their employability and on-going professional development.

At the first session there was no lecture. The tutor talked through the assessment criteria, which had been sent to the participants before making their choices. The tutor said that as participants they would have clear ideas about aspects of their programme they might like to investigate. The intended learning outcomes were as follows:

Participants then started to discuss what they thought were important issues for their work. They spent some time discussing aspects of assessment and came to the conclusion that they would work as one group on the project. In the end they chose school-university links. In the previous semester they had been in schools on teaching practice so this was a topic that was current for them. Rules for anonymity, privacy and ethics were discussed and agreed. Participants would also have to gain ethics approval for their project. They were given readings by Samuels and Betts on self-evaluation of reflective writing, an article that pointed out that following the approach advocated students gained higher grades. They were also asked to read Dunne and Zandstra (2011), HEA 
(2012) and Gawker (2005). Participants were surprised that this discussion had taken three hours. There had been some initial discussion on methods and a research question. School university links was the focus and there was some discussion of questionnaires and interviews. Each session was evaluated using a different approach, e.g. reflective writing drawing on Brookfield and Preskill (1999). This was a way to introduce formative module evaluation rather than the summative evaluation more typical of the sector. The tutor wrote his reflections and posted it on the participants' virtual learning network. The aim was to show what the tutor thought reflection might be

The approach to teaching research methods was emergent. Rather than be taught research methods, participants were to learn research by carrying out a project. The role of the tutor was to see what people wanted to research and then to suggest ways to do it. The approach taken here might go some way to bridging the divide between researchers and classrooms as the aspiration is that participants are becoming teachers as well as becoming researchers.

At the second session, it was clear that school university links was to be the main focus. They also wanted to understand the points of view of individuals involved from both undergraduates and from university staff. School-university links are much discussed in the literature with many arguing that there are few connections between school and university. Zeichner (2010 p400) argues that one way to resolve this problem is for the teachers to become creators of knowledge, to be involved in research

The teachers in our study desired more direct, visible connections between research and their daily practices. In alignment with Foucault's (1977) knowledge - power discourse, this desire challenged the authority of global theories (i.e. academic research) and called our attention to local contextualized knowledge (i.e. classroom practice). This finding also confirmed the existence of traditional power hierarchies in the Ontario education community (Foucault 1980). The traditional top-down approach where the teacher is positioned at the bottom of the 'knowledge funnel', being handed somebody else's research-based 'best practices' to implement - is still firmly in place and was criticized by focus group participants.

At the start of the second session, participants presented outcomes from their reading. The tutor reflection identified the power of experiencing methods as a way to come to understand them. Eraut (2007) argues that where knowledge is presented in books or lectures it is decontextualized and not available for use. In this project the aim is to use, develop and create knowledge so an emergent, experiential approach to teaching research methods was taken. The tutor then introduced two approaches back tracking (Ryan 2003) and forced pair choices (Kumar 2003). Participants preferred forced pair choices. Participants are asked to identify the links that they saw between school and university. This generated a list of possible links. Participants were then asked to consider all the possible pairs and choose which in their opinion was more important. By the end of the procedure there is a hierarchy of links. The group then discussed what they thought of the hierarchy generated and the tutor made links to the hierarchy that had been produced and issues such as validity, reliability and dealing with analysis of qualitative data. An example of such a hierarchy is given in Table 1 . This was produced by the pilot group as the demonstration exercise. During the programme students have to arrange self-directed experience in schools, usually to meet agreed action plan criteria. The high priority it gets probably reflects the fact that participants are clear on their agendas for this experience.

Table 1. Pilot group rankings of school university links

\begin{tabular}{|c|c|}
\hline Item & Priority \\
\hline Self directed school based work and international experience & 9 \\
\hline Lectures and seminars & 7 \\
\hline Feedback on assignments & 6 \\
\hline Assessment & 5 \\
\hline Lecturers who used to be teachers & 5 \\
\hline Readings & 5 \\
\hline Profesional development Tutor & 4 \\
\hline Action plans & 3 \\
\hline Directed tasks & 1 \\
\hline Visiting speakers & 1 \\
\hline
\end{tabular}

Participants had already identified possible participants in the school-university links project. The programme has about 200 students with groups of about 25 nominating two people to speak about their concerns within the consultation and committee structure of the university. They decided that these spokespeople should be their target group. They are involved at a programme level and so they were likely to have a richer understanding of structures and procedures. Eight people agreed to take part. The participants from the module decided that they would ask each person to generate a list, carry through the forced pair choice activity and then comment on the outcomes. They were then interviewed about their experiences in school and how that connected to the university. A chart showing the nature of teacher development taken from Shulman and Shulman (2004) was used as a basis for discussing the priority charts and school university links. This chart gives Shulman and Shulman's view of teacher becoming, where reflection is seen as the way to connect teacher vision, motivation, understanding and practice. The interviewees were asked to comment on the diagram and how that related to the priorities they had established in their school - university links. Finally, interviewees were asked to suggest ways to strengthen such links.

The tutor suggested that carrying out such tasks had to be learnt. Participants agreed that they would try out the activities with other course members as a pilot to identify issues and clarify procedures and questions. The following week they fed back on the experience and appreciated the importance of such pilot work. Participants identified university staff at different levels, the head of department where the programme sits, the organized of school experience, the course director, tutors who work with students in school and teachers in school who act as link tutors. In the tight time-scale of the project it was not possible to work with teachers in school. Participants worked in pairs to carry out the research activities and agreed to present their findings two weeks later. These were analysed the following week with the forced pair choices being tabulated for students and for tutors. The interviews were analysed for key phrases and ideas to act as a check on the data included in the tables and act as triangulation. They then prepared their findings which 
they presented at a faculty research seminar. They devised a name for their research group, Insider Researchers of Undergraduate teacher education, IRUPTE, which also shows some of their intentions to be change agents.

The final session involved a discussion of the learning from preparing and presenting the research seminar and a review of the module using nominal group technique (Clarke, Egan, Fletcher and Ryan, 2006). The questions they were asked were:

1. What for you are the major learning outcomes?

2. What comments and suggestions do you have?

3. What more could you the student have done to improve your learning?

4. What more could your tutor have done to improve your learning?

5. What comments do you have on weekly evaluations?

Participants had met many of the aspects of carrying through a research project that they might meet on a research methods course. In this case, it was in the context of the practice of research rather than in a lecture theatre. They had gone through a range of research methods and the issues around them, such as reliability and validity, and presented their findings.

After the end of the module, participants also showed that they were keen to be change agents and support programme development by working in their free time (Dunne and Zandstra 2011, HEA 2012). They presented their findings at a faculty staff development workshop, a university workshop on teaching and learning and also to a training day for staff and teachers who act as link tutors during teaching practice.

\section{Discussion}

Table 2. Tutor and student rankings of perceptions of the importance of the link

\begin{tabular}{|c|c|c|c|}
\hline \multicolumn{2}{|l|}{ Tutors } & \multicolumn{2}{|l|}{ Students } \\
\hline Professional practice seminars & 12.0 & School partnership office & 12 \\
\hline School experience handbook & 7.9 & Self-directed placements & 12 \\
\hline School partnership office & 7.4 & PDT's & 12 \\
\hline Link tutors & 6.7 & Placements & 12 \\
\hline Placements & 6.4 & Lectures and seminars & 10 \\
\hline PDT's & 6.0 & Projects and trips & 9 \\
\hline Seminars & 5.6 & International experiences & 7 \\
\hline Experiences in seminars & 5.3 & Practicals & 7 \\
\hline Action plans & 4.6 & Peer support & 7 \\
\hline Workshops & 4.6 & Subject knowledge & 6 \\
\hline Off-site activities & 4.2 & Library and resource base & 6 \\
\hline Tutors personal experience & 3.5 & Volunteering A & 5 \\
\hline School experience forms & 3.5 & Link Tutors & 5 \\
\hline Teacher tutor & 3.2 & Assignments & 4 \\
\hline Visiting speakers & 3.2 & Student services & 4 \\
\hline Teacher tutor training & 3.2 & Professional studies & 3 \\
\hline Learning network & 3.0 & teaching ideas & 2 \\
\hline Group work tasks & 2.8 & Professional Practice & 2 \\
\hline Research projects & 2.8 & Handbooks & 2 \\
\hline School based modules & 2.5 & Visiting speakers & 1 \\
\hline Journals & 2.1 & Learning network & 1 \\
\hline School experience lectures & 1.4 & Year 3 Maths & 0 \\
\hline Student services & 1.4 & & \\
\hline Standards tracker & 1.4 & & \\
\hline Link tutor training & 1.4 & & \\
\hline Assignments & 0.7 & & \\
\hline Readings & 0.0 & & \\
\hline Lectures & 0.0 & & \\
\hline
\end{tabular}

The data sets used as a basis for the discussion are the data from the participants' research project, outcomes of the NGT activity, interviews with the participants, and commentaries they sent the tutor. The discussion will be organized through the outcomes of the student research project and then around the participants learning as a reflective learner, a becoming research and a becoming teacher, which overlap in the complexity of participant thinking.

The research project showed that contrary to some views in the literature (Zeichner 2010), the undergraduate students they worked with typically identified five or six possible links between school and university. The overall order of priority for tutors and students is given in Table 2. The numbers have been normalized for comparison.

A score of zero in the figures should be taken positively. It means that somebody identified these as links, links that are of lesser importance than the others. The office that organizes placements and administers the practice comes at the top of the priorities for both staff and students. The literature on school-university links pays little attention to such topics. Interviews with students showed the value of knowing the people in the office by name, who they are and their responsibilities. This is a call for a relational way of knowing. As a result of presentations done by members of IRUPTE, the briefing session for students for each practice includes presenting people from the office to the students so they know something about them. This was a simple change to introduce and shows the value of involving students in research their peers' experiences. Students throughout the programme have a professional development tutor (PDT). They meet with the student each semester to discuss student progress. For the students the importance they attach to this as a way of linking school and university seems not to be matched by the staff. However, the action plan, is completed by the student at the end of each practice with the help of their link tutor and is often the basis for their meeting with their PDT. There are some differences as we might expect in an area that involves cognitive, affective and social dimensions that is teaching practice. Professional practice seminars, which features as a very high priority within the tutors list seems to be absent from the students list though it would be inside the student list as 'lectures and seminars'. What the data shows is that in this programme, students at this stage are able to identify a number of ways that school and university link, contrasting with the view in the literature (Zeichner 2010). That tutors, who would be expected to have thought carefully about their programme, are able to identify twice as many links as third year students might well be expected, especially the attention given to the topic in the literature and in the statutory requirements and programme review criteria of the government (TDA 2006).

Table 3 gives the items most suggested by students and tutors to improve school university links.

These findings were presented to the staff responsible for placements and for the programme. As discussed above, administrative staff are now introduced to the student cohorts when they have their briefings for working in school. The course is moving to making some of the other changes suggested such as school-based projects. These projects will also meet some of the other suggestions of increasing time in school and a more school focused approach within modules. Some of the participants in the research project also realised that they could act and not wait for tutors to set up electronic forums; they could do it for themselves. Certainly there 
are several groups now on various social media, though it is not clear whether they are an outcome from this research project.

Table 3. Suggestions for improving school- university links

\begin{tabular}{|c|c|}
\hline $\begin{array}{c}\text { Student suggestions } \\
\text { experience forums. }\end{array}$ & Tutor suggestions \\
\hline $\begin{array}{c}\text { More time in school and more } \\
\text { interaction with children and teachers } \\
\text { in university. }\end{array}$ & $\begin{array}{c}\text { Improved use of technology; } \\
\text { podcasts with student advice } \\
\text { for future practice. }\end{array}$ \\
$\begin{array}{c}\text { Introducing the idea of home } \\
\text { schools, in order to build up a } \\
\text { relationship with a school on a } \\
\text { weekly basis. }\end{array}$ \\
$\begin{array}{c}\text { University tutors as link tutors and } \\
\text { more consistency with link tutor and } \\
\text { teacher tutor guidance. }\end{array}$ & $\begin{array}{c}\text { Students being more proactive } \\
\text { in their personal development, } \\
\text { particularly whilst in school. }\end{array}$ \\
\hline $\begin{array}{c}\text { More interaction with school } \\
\text { partnership office pre- and post- } \\
\text { school experience, so that students } \\
\text { feel more comfortable approaching } \\
\text { them. }\end{array}$ & $\begin{array}{c}\text { More school based projects and } \\
\text { modules. }\end{array}$ \\
\hline $\begin{array}{c}\text { More practical based modules in } \\
\text { order to aid student learning. }\end{array}$ & $\begin{array}{c}\text { More practical input in } \\
\text { university module sessions. }\end{array}$ \\
\hline
\end{tabular}

\section{Participant Outcomes}

As this is a module within an award bearing course, an important focus has to be on the participants learning as undergraduates. However, such aspects will be reported elsewhere. The focus in this paper will be on the participants becoming reflective, becoming researchers and as becoming teachers. At the end of the module, the module evaluation was carried out using Nominal Group technique. In response to the NGT question 'What for you are the major outcomes?' the leading items prioritized by participants were

- Being able to be reflective. Understanding the research process.

- Research approach/procedure. How students actually feel about university and school experience. The interest of lecturers.

- For me personally I have learned how to create a research project whilst reflecting on my own practice/take on the research outcomes.

- That the partnership between school and university is crucial in our development as great teachers. This however needs to be supported by the lecturers themselves whilst at school and university.

\section{Becoming Reflective}

Interviews show that the growing ability to be reflective comes from tutor expectations and modeling (Claxton 2006, Claxton, Chambers, Powell, and Lucas, 2011).

Right from the go, reflections were a key part that [tutor] expected. The idea was to deepen reflection; we weren't used to that way of doing things. I tried Samuel and Betts then we used one of [tutor]'s reflections to analyse as such and create more and more. That and identify readings from that

I feel much more on top of everything after having sat and typed all my reflections so that my thoughts are on paper as opposed to filling my head. It's surprising how easy it has become to reflect on my thoughts since this module. I now also see the benefit of it more as well, as it helps to develop my thinking by thinking out loud, but on paper. This way my points seem clearer when written and then easier to expand on further as I don't have to remember everything because it is written down for me.

Ward and McCotter [2004) say tutors say can you reflect on that; but have we ever thought what a good quality reflection is. Students don't automatically know what is a good reflection. That made me reflect have I done a good reflection. Now I think am I giving it the quality or going with the first thing I did. Many people think I'm only doing it for the sake if the outcome they'll never check on that. They said their students said it was fluff, merely an activity to get an outcome. Reflection should be the student's tool. I need to do it to get an outcome.

The participants were working together on a project that they were committed to. The experience of reflection seems to have helped them in that process without meeting the negative impacts of critical reflection that might arise where the person reflecting feels unable to act on their reflection (Reynolds 2011)

\section{Becoming Researchers}

In interviews, participants chose the topics that they wanted to discuss; the issue of data collection and analysis came up frequently. They also saw the impact of being committed to a research topic on which they personally had strong views, the difficulty of being both an insider and trying to be an outsider (Mercer 2007).

Yes. A strange irony. It's really difficult not to put your opinions on your interviews. I wrote here it's really difficult to say what a link is without influencing their choices.

While there was significant debate around how to collect the data, data analysis was seen to be rather more challenging.

Sometimes it's better to take me out of the situation. With the data analysis it's difficult not to say they meant that, which is what I think. For us it was personal, it's because of the ownership, the motivation. That's definitely a big thing. But I did enjoy being challenged. I'd never even consciously heard of a critical incident before. Now I keep it in mind. Whereas now, it's consciously making me know think what do they mean by it what is the outcome is it different from what they thought it would be.

Here the participant is making connections between their research process and what they were used to reading as part of their studies. There is a realization that the texts they read have been constructed. There was also a suggestion that a participatory approach to data analysis might be a good way forward.

Analysing the data, we thought it wouldn't take long but it took a long time. I'd like the participants to be there to ask them do you mean that or do you mean that.

There is a long tradition in the U.K. for teachers to be investigating and developing their own practice (Stenhouse, 1976). The approach adopted in this module seems to have helped participants make the connections between their research and practice as well as between research and practice in general. 
Definitely. I feel a lot more... enthusiastic about doing the [dissertation]. Before knowing that the dissertation is a research project at the end I was dreading the whole way through. Personally I didn't have an interest in research. In teaching I didn't see the benefits of research I can now see the benefits of doing research in a school setting, as a teacher within school, to find out what's happening to find out things you wouldn't know unless you were doing research and where it's heading.

\section{Becoming Teacher}

They also drew lessons from their experience of taking charge of learning for future practice.

What we found out was really relevant for our practice. It made us realise that what we do now at university and what the tutors are expressing and what we do now really influence our future practice.

I'd written essays about the importance of being a facilitator. It was when, when I had this experience I realise how it feels, what the advantages are, see it from the inside. Watching [tutor] showed what it was like in practice. It becomes real.

Here we see echoes of Eraut (2007). There is a move from inert knowledge, perhaps good enough for an essay to active knowledge, to knowing what it feels like and might do in practice. What reflecting on their experience also provided was an insight to teaching and learning. They saw value in allowing the pupils to start to take control and the roles they might have as change agents or researcher in that context (Fielding 2007).

Being a classroom researcher, like Thomson and Gunter [2006] say, evaluative thinking, and doing research with children. That gives them that voice. They have opinions and can voice them, in choosing what to do. Know what their opinions are.

Shulman [Shulman and Shulman 2004) says you have to understand, not just know, to be able to teach. One thing I learnt from the critical incident is you need to see one incident from many perspectives, to take yourself away from the incident emotionally. In school you're gonna have 30 children all tackling a maths problem at the same time in different ways. You're gonna have to understand each view. I think that's what helped me in terms of teaching pupils.

Looking back I haven't used team work in school. I was with a close friend and so I felt comfortable asking for advice. I've been reluctant to ask them. It's like gaining their trust. I didn't know everybody in the group. I think I have to put into it what I want to get out of it. In school you have to work together. It's almost hard not to take it personally. I've made a mistake how can we move on from that. Can children be in that collective? In the past you're so focused on 'being a teacher' you forget about the children. It's more about them being involved as well as the staff..

The value of listening to the children rather than going in like a steamroller. This is my idea. In this module, we were very much sort of this is what you've got to do and then it's up to you. In some other modules were told what to do and when. I was in a classroom; the curriculum was partly decided by the children. What would you like to learn? What do you want to find out? I saw it in school and they were all learning something they thought was valuable and none of them trailed off and got lost.

\section{Conclusion}

The approach taken here to investigating peers' experiences of a programme seems to make important contributions to participants becoming reflective, becoming researchers and becoming teachers. These are much sought after but less seen outcomes of initial teacher education (Zeichner 2010). Participants drew on their experience to draw lessons for themselves as learners, as becoming researchers, and as becoming teachers. These reflections seem to relate to their ways of being and their ways of interacting with their future students. Carr and Kemmis (1986) argue that teacher research might be classified as technical, practical or emancipatory. The technical approach is towards control where external researchers decide the research purposes and the teachers' roles are to see how they might answer these questions. In the practical orientation, the focus is on understanding the context, in this case school university links. A critical or emancipatory orientation has as its focus the search for means to empower individuals so they can help bring about societal change. The participants in this project show that they are becoming critical, wanting to change student experience for the better and also seeing that their future students can and should be allowed to flourish as they have. They see themselves as becoming researchers able to create knowledge, which may be more likely to influence their future practice (Hargreaves 1999). They have moved beyond simple dichotomies such as theory/ practice to a more nuanced view. The skills they have developed as becoming teachers, becoming researchers and curriculum creators should stand them in good stead for the challenges they will meet in the many changes that this century will bring. They seem to becoming accomplished teachers that envisaged by Shulman and Shulman (2004, p259)

We would now stipulate that an accomplished teacher has developed along the following dimensions: An accomplished teacher is a member of a professional community who is ready, willing, and able to teach and to learn from his or her teaching experiences [Emphasis in original].

\section{References}

[1] Avalos, B., Teacher professional development in Teaching and Teacher Education over ten years, Teaching and Teacher Education, 27 10-20. 2003.

[2] Beauchamp, G., Clarke, L., Hulme, M., and Murray, J. Research and Teacher Education: The BERA-RSA inquiry. Policy and Practice within the United Kingdom. Project Report. British Educational Research Association, London, 2013.

[3] Brookfield, S. D. and Preskill, S. Discussion as a way of teaching: tools and techniques for university teachers, Society for Research into Higher Education and the Open University, Buckingham, 1999.

[4] Chambers, R., Participatory Workshops: a sourcebook of 21 sets of ideas and activities, Earthscan, London 2002.

[5] Clarke, H., Bridget Egan, B., Fletcher, L. and Ryan, C., Creating case studies of practice through appreciative inquiry, Educational Action Research: an International Journal 14 (3) 407-422. 2006. 
[6] Claxton, G., Expanding the Capacity to Learn: A new end for education? British Educational Research Association Annual Conference 6 September 2006 Warwick University, 2006.

[7] Carr, W. and Kemmis, S. Becoming Critical, Falmer Press Lewes. 1986

[8] Claxton, G. Chambers, M. Powell, G. and Lucas B., The Learning Powered School-Pioneering 21st Century Education, TLO, Bristol. 2011.

[9] Cordingley, P. Research and Teacher Education: the BERA-RSA Inquiry: The contribution of research to teachers' professional learning and development, CUREE, Warwick 2013, at http://www.curee-

paccts.com/files/shared/BERA\%20Paper\%205\%20Continuing\%2 Oprofessional\%20development\%20and\%20learning.pdf (accessed 23/05/2014)

[10] Cordingley, P. and Bell, M., Transferring learning and taking innovation to scale, CUREE, Warwick. 2007

[11] Dunne, L. and Zandstra, R., ESCalate, Students as Change Agents-New ways of engaging with learning and teaching in Higher Education, University of Exeter/ESCalate/Higher Education Academy Publication. 2011. Available at http://www.cumbria.ac.uk/Public/Education/Documents/Research/ ESCalateDocuments/StudentAsChangeAgents.pdf

[12] Elliott, J. Action research for Educational Change, Open University Press, Milton Keynes. 1991.

[13] Elliott J and Adelman C (no Date) Developing Hypotheses about Informal learning, Norwich, CARE see also the version available at

http://ndsg.org/monographs/NDSG_1976_Elliott_Developing_Hy potheses.pdf

[14] Eraut, M., Learning from Other People in the Workplace, Oxford Review of Education, 33 (4) 403-422. 2007.

[15] Fielding, M. Beyond "voice": new roles, relations and contexts in researching with young people, Discourse: Studies in the Cultural Politics of Education 28 (3) 301-310. 2013.

[16] Gawker, M., Useful Tools for Engaging Young People in Participatory evaluation, UNICEF CEE/CIS. 2005.

[17] Hargreaves, D. H., The knowledge-creating school, British Journal of Educational Studies, 47: 122-144. 1999.

[18] Hatton, N. and Smith, D. (1995) Reflection in teacher education: Towards definition and implementation, Teaching and Teacher Education, 11 (1) 33-49. January 1995.

[19] HEA, Dimensions of Student Engagement, HEA York. 2012 at accessed 29/11/12

[20] http://www.heacademy.ac.uk/resources/detail/studentengagement/ Dimensions_student_engagement

[21] Hargreaves, D.H. 1999. The knowledge creating school. British Journal of Educational Studies 47, no. 2: 122-44.

[22] Kreber, C. Authenticity in and through Teaching in Higher Education, Routledge, London. 2013.

[23] Korthagen, K., Loughran, J. and Russell, T., Developing fundamental principles for teacher education programs and practices, Teaching and Teacher Education, 22 (8) 1020-1041. 2006.

[24] Larrosa, J., "Conferencia: La experiencia y sus lenguajes." Serie $<<$ Encuentros y seminarios $>>$, en línea: http://www.me.gov.ar/curriform/publica/oei_20031128/ponencia larrosa.pdf. 2009, Accessed 29/05/2014.

[25] MacLellan, E. How reflective is the academic essay? Studies in Higher Education, 29:1, 75-89. 2004.

[26] Mercer, J., The challenges of insider research in educational institutions: wielding a double-edged sword and resolving delicate dilemmas, Oxford Review of Education, 33:1, 1-17. 2009.

[27] OECD, Attracting, developing and retaining effective teachers, OECD, Paris. 2005

[28] From http://www.oecd.org/document/9/0,2340,en_2649_34521_119695 45_1_1_1_1,00.html.

[29] Reason, P. and Bradbury, H. (Eds.) Handbook of Action Research Participative Inquiry and Practice, London Sage Publications. 2001.

[30] Reynolds, M., Reflective practice: origins and interpretations, Action Learning: Research and Practice, 8:1, 5-13. 2011.

[31] Ryan, C., Falando e escrevendo sobre a criação do currículo e a formação dos professores, [Talking and writing teachercurriculum-development] Leitura 59 pp 4-16. 2012.

[32] Ryan, C., Becoming a teacher of primary science: integrating theory and practice, Teachers and Teaching: Theory and Practice, 9 (4) pp 333-350. 2003.

[33] Samuels, M. N. and Betts, J. Crossing the threshold from description to deconstruction and reconstruction: using selfassessment to deepen reflection. Reflective Practice, 8 (2). pp. 269-283. 2007.

[34] Shulman L.S. \& Shulman J.H., How and what teachers learn: a shifting perspective, Journal of Curriculum Studies, 36:2, 257-271 2004.

[35] Tandon, R., In Search of Relevance: Higher Education for Participatory Research and Sustainable Development, in Reinventing Higher Education: Toward Participatory and Sustainable Development, Bangkok: UNESCO Bangkok, 42-50. 2008

http://unesdoc.unesco.org/images/0016/001631/163155e.pdf accessed 24/05/2013.

[36] TDA, Handbook of Guidance, London, TDA, London. 2006.

[37] Thomson, P. \& Gunter, H., From 'consulting pupils' to 'pupils as researchers': a situated case narrative, British Educational Research Journal, 32:6, 839-856. 2006.

[38] Ward, J. R., \& McCotter, S. S. Reflection as a visible outcome for preservice teachers. Teaching and Teacher Education, 20, 243257. 2006.

[39] Zeichner K.M., Rethinking the connections between campus courses and field experiences in College-and University-based teacher education, Journal of Teacher Education, 61 (1-2) pp 8999. 2010.

[40] Zeichner, K., Research on teacher thinking and different views of reflective practice in teaching and teacher education, in Teachers' Minds and Actions: Research on Teachers' Thinking and Practice, Handal, P.G. and Vaage, S. Routledge, London, 11-28, 1994.

[41] Zeichner, K. and Liu Y., A critical analysis of reflection as a goal for teacher education. In N. Lyons (Ed.). Handbook of Reflective Inquiry. Springer, New York. 2010. 